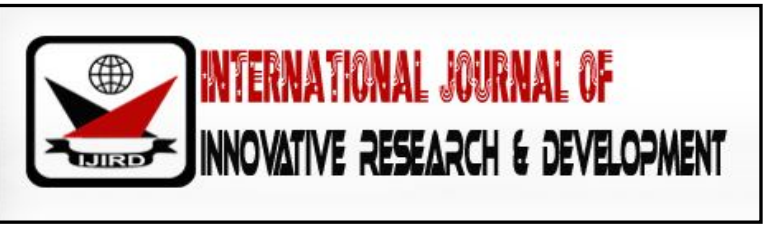

ISSN 2278 - 0211 (Online)

\title{
Prevalence and Antimicrobial Susceptibility of Potential Bacterial Pathogens at Some Selected Abattoirs in Port Harcourt, Nigeria
}

\author{
Catherine Nonyelum Stanley \\ Senior Lecturer, University of Port Harcourt, Nigeria \\ Faith Chinaemerem Diorgu \\ Senior Lecturer, University of Port Harcourt, Nigeria \\ Malachy Chigozie Ugwu \\ Senior Lecturer, Nnamdi Azikiwe University, Nigeria
}

\begin{abstract}
:
Bacteriological evaluation of four different abattoirs in Port Harcourt was carried out to determine the prevalence of pathogenic microorganisms at these sites and their susceptibility to antimicrobial agents. Samples were collected by swabbing the surfaces of tables used in displaying meat at these abattoirs. The spread plate method was used for the inoculation and microbial counts, while the streak plate method was used for the isolation of pure culture from the mixed culture. The antibiotic susceptibility of the isolates was done using the disc diffusion method. Nine (9) different species of bacteria were isolated from the eighty (80) samples collected and these include Escherichia coli, Pseudomonas aeruginosa, Staphylococcus aureus, Streptococcus pyogenes, Klebsiella pneumonia, Bacillus cereus, Micrococcus luteus, Shigella dysenteriae and Salmonella enteritidis. Out of three hundred and thirty sixty (336) isolates, E.coli accounted for $72(21.43 \%)$, Staphylococcus aureus 51 (15.18\%), Pseudomonas aeruginosa 45 (13.40\%) and Salmonella enteritidis19 (5.65\%) respectively. The mean total microbial count was $1.23 \times 10^{7} \mathrm{cfu} / \mathrm{ml}$. Among the Gram-negative bacteria, E.coli was susceptible to all the antibiotics used while Shigella spp showed the highest level of resistance. Among the Gram-positive bacteria Staphylococcus spp was susceptible to all the antibiotics used, while Bacillus spp showed the least susceptibility. In view of the level of pathogenic organisms isolated from the abattoirs it is likely that meat displayed on these contaminated tables may also be contaminated. It is therefore recommended that hygiene and sanitary conditions be improved and meat properly cooked to eliminate harmful bacteria that are known to cause food poisoning. Prudent use of antibiotics in animal husbandry is also advised to help control the emergence of antibiotic resistance.
\end{abstract}

Keywords: Abattoirs, antimicrobial susceptibility, E. coli, P. aeruginosa, S. aureus, S. pyogenes, K. pneumonia, B. cereus, M. luteus, S. dysenteriae and S. enteritidi

\section{Introduction}

In Nigeria, the development and growth of livestock production has been on the increase providing steady supply of food animals for slaughter and processing for human consumption. The daily demand for meat which serves as a major protein source is quite high.

The abattoir is the place where livestock such ascattle and goats are slaughtered, processed and distributed for human consumption as well as for other industrial purposes (Onuoha, 2016). The term 'abattoir' was derived from the French word 'abattre' meaning "to strike down"(Alonge, 2005). Although an abattoir is principally a place where livestock are slaughtered, its design, construction and ownership vary from state to state (Marriott, 2004; Omoruyi et al., 2011). Livestock products are highly perishable and unless correctly processed, packaged, stored, and distributed are prone to microbial spoilage which poses hazard to health. A combination of factors such as the condition of the animal prior to slaughter, abattoir environment and practices, extent of handling and subsequent storage condition contribute to the potential for microbial contamination (Onuoha et al., 2016).

Furthermore, compared to the advanced countries where waste generation, analysis and treatment are considered before constructing abattoirs (Ogbonnaya, 2008), abattoirs are generally less developed in resource limited countries like Nigeria. The use of contaminated water and instruments for washing and cutting, and unhygienic practices like poor handling 
and display of meat for sale on contaminated tables expectedly result in high level of contamination of livestock products offered for sale. With respect to pathogen contents, natural toxins and other possible contaminants and adulterants, meat and meat related products are generally regarded as high-risk commodities (Yousuf et al., 2008; Okonko et al., 2010). Contamination of meat and meat products occur when raw meat is exposed to pathogenic microbes which are ubiquitous in nature (WHO, 2003). Microbial contamination of meat and meat products must not exceed minimum accepted levels above which the shelf life of the product would be adversely affected thus rendering it distasteful and unfit for human consumption (Fasanmi \& Sanusi, 2008).

Abattoir practices in Nigeria are generally poor and unsatisfactory. Slaughtering is generally carried out on the floor and outside the abattoir by individual butchers, with little or no concern for hygiene, a practice that could be readily observed in slaughter sites located across major cities in Nigeria (Ugwu et al., 2016). High ambient temperatures, heavy fly and rodent infestations prevalent in abattoirs encourage the contamination of meat (Nwachukwu, 2006; Abiade et al., 2006). The unhygienic transportation of meat is approaching disaster level as carcasses are transported in boots of taxis, dirty pickup vans, motor cycles, carts and wheel barrows. Street hawking of meat in open head pans is increasing in many cities. Besides compromised quality, microbial contamination of meat could result in major public health challenge such as massive food poisoning. Although it is difficult to attain 100\% level of hygiene in abattoirs, the traditional methods of handling, processing and marketing of meat adopted in most developing countries undermine quality and predispose to loss of products and risk of food-borne disease (Gill \& Jones, 2005, Garcia, 2007).

A number of studies have reported outbreak of infections due to consumption of contaminated food and poor hygiene (Alonge, 2005; Mohammed et al., 2014). Some community-based reports have also provided evidence of several outbreaks caused by Salmonella, Shigella, E. coli and Listeria species in different parts of the world (Elmossalami, 2003; Alonge, 2005; Zweifer et al., 2008; Onuoha et al., 2016). Health consequences arising from consuming contaminated meat or food range from protracted illness to death and patients with impaired immunity are at greater risk (Iroha et al., 2011).Lack of proper management of waste generated by abattoir operation not only pose a significant environmental hazard but also contribute to emergence of multidrug resistant pathogens with potential for transferring antimicrobial resistance patterns. International best practices require the adherence to standards of quality with respect to the design, construction, management and maintenance of abattoirs and slaughter slabs as well as adherence to standard practice of meat inspection and sanitation which ensures that public health is not compromised. Inspection of live animals and the carcass plays a key role in the surveillance network for animal diseases and ensures the safety and suitability of meat and their by-product for their intended uses (Mboto et al., 2012).

The poor state of abattoirs and meat processing plants, absence of meat inspection services and the resultant consumption of unwholesome meat by the public have become a major cause for concern to all stakeholders and the general public. In spite of the passage of time there has not been much improvement in abattoir practices in Nigeria.This study was therefore, conducted to determine the prevalence of potential pathogenic microorganisms at some designated abattoirs in Port Harcourt and their susceptibility to antimicrobial agents.

\section{Materials and Method}

\subsection{Sample Collection}

A total of eighty (80) samples were collected from surfaces of tables used in displaying meat in different abattoirs in Port Harcourt using sterile swab sticks. Twenty (20) samples each were collected from Choba, Rumuokoro, Trans Amadi and Ogbunabali respectively representing Abattoirs in Port Harcourt and its environs.

\subsection{Sample Culturing and Purification}

Sterile swab sticks were used to collect samples by the moisture swab technique and taken to the laboratory for microbiological analysis within 6 hours of collection (Fasanmi et al., 2009).

Each sterile swab stick was moistened with 1\% sterile peptone water and rubbed firmly over the defined surface $(10 \mathrm{~cm} \mathrm{X} 10 \mathrm{~cm})$ that was to be analyzed using parallel strokes with slow rotation of the swab and then repeating this at right angles to the first set of strokes (Harrington \& MaCance, 1976). This procedure was repeated for all the samples collected from all the four abattoirs.

\subsection{Identification and Confirmation of Isolates}

The streak method is a simple and rapid method of diluting the sample by mechanical means. As the loop is streaked across the agar surface, more and more bacteria are rubbed off until individual separated organisms are deposited on the agar. After incubation, the area at the beginning of the streak pattern will show confluent growth while the area near the end of the pattern shows discrete colonies (Kaiser, 2012). Plates showing well isolated and distinct colonies were selected after enumeration of the colonies. The selected colonies represented all the different isolates present in each sample judging from their colonial characteristics. They were all carefully labelled, sub-cultured by streaking on fresh pre-dried agar plates and incubated at $37^{\circ} \mathrm{C}$ for 24 hours. Purity of each isolate was confirmed by colonial morphology and Gram staining. Those found to be mixed cultures were further sub-cultured and Gram stained (Harrigan \& McCance, 1976; Kaiser, 2012). Hence, isolate 
was identified on the basis of morphological characteristics (shape, colour, size, edge and number of colonies), Gram staining reactions and biochemical reactions (catalase, indole, oxidase, citrate and coagulase tests) using the standard as described in Bergey's manual for identification of isolates.

\subsection{Biochemical (Catalase, Indole, Oxidase, Citrate and Coagulase) Tests}

These tests were done for the actual identification and characterisation of the bacteria. This was assessed by the ability of bacteria to use enzymes to degrade carbohydrates, proteins, or amino acids.

\subsection{Antimicrobial Screening/ Sensitivity Studies}

Susceptibility patterns of the isolated organisms were tested against a wide range of antibiotics using antibiotics discs impregnated with known concentration of an antimicrobial agent and placed on a plate of solidified agar uniformly inoculated with the test organism. The antibiotics include the following: Ofloxacin (OFX) 10mcg, Pefloxacin (PEF) 10mcg, Ciprofloxacin (CFX) 10mcg, Augmentin (AU) 30mcg, Gentamycin (GN)10mcg, Streptomycin (S) 30mcg, Cephalexin (CEP) 10mcg, Nalidixic acid (NA) 30mcg, Co-trimoxazole (SXT) 30mcg, Ampicillin (PN) 30mcg, Norfloxacin (NB) 10mcg, Amoxicillin (AML) 20mcg, Rifampicin (RD) 20mcg, Erythromycin (E) 30mcg, Chloramphenicol (CH) 30mcg, Ampicillin/ cloxacillin (APX) 20mcg, Levofloxacin (LEV) 20mcg. All antibiotics were supplied by MaxiCare Medical Laboratory, Nigeria LTD.

\section{Results}

A total of nine (9) different species of bacteria were isolated from all the eighty (80) samples. The various types of bacteria isolated are Escherichia coli, Pseudomonas aeruginosa, Staphylococcus aerus, Streptococcus pyogenes, Klebsiella pneumonia, Bacillus cereus, Micrococcus luteus, Shigella dysenteriae and Salmonella enteritidis. The number and percentage occurrence of each individual bacterium encountered are presented in Table 1-3.

\begin{tabular}{|c|c|c|c|c|c|c|c|c|}
\hline Colonial Morphology & $\begin{array}{c}\text { Cell } \\
\text { Morphology }\end{array}$ & $\begin{array}{c}\text { Gram } \\
\text { Reaction }\end{array}$ & CAT & IND & $\mathbf{C I T}$ & OXID & COAG & $\begin{array}{c}\text { Bacteria } \\
\text { Identification }\end{array}$ \\
\hline $\begin{array}{c}2 \mathrm{~mm} \text {, creamy, circular } \\
\text { and convex }\end{array}$ & Rod & - & + & + & - & - & - & Escherichia coli \\
\hline $\begin{array}{l}2 \text { mm, greenish, yellow } \\
\text { circular, entire and } \\
\text { convex }\end{array}$ & Rod & - & + & - & - & + & - & $\begin{array}{l}\text { Pseudomonas } \\
\text { aeruginosa }\end{array}$ \\
\hline $\begin{array}{l}2 \text { mm, cream circular, } \\
\text { entire and convex }\end{array}$ & $\begin{array}{l}\text { Cocci in } \\
\text { cluster }\end{array}$ & + & + & - & - & - & + & Staphylococcus aerus \\
\hline $\begin{array}{l}3 \mathrm{~mm} \text {, greenish circular, } \\
\text { entire and convex }\end{array}$ & $\begin{array}{l}\text { Cocci in } \\
\text { chains }\end{array}$ & + & - & + & + & - & - & $\begin{array}{l}\text { Streptococcus } \\
\text { pyogenes }\end{array}$ \\
\hline $\begin{array}{l}\text { 2mm, creamish-white, } \\
\text { circular and convex }\end{array}$ & Rod & - & + & - & + & - & - & Klebsiella pneumonia \\
\hline $\begin{array}{c}3 \mathrm{~mm} \text {, white, irregular, } \\
\text { undulated and flat }\end{array}$ & Rod in chains & + & + & + & - & - & + & Bacillus cereus \\
\hline $\begin{array}{l}\text { 1mm, yellow, circular } \\
\text { and convex }\end{array}$ & Cocci & + & + & - & - & - & - & Micrococcus luteus \\
\hline $\begin{array}{c}2 \mathrm{~mm} \text {, brownish } \\
\text { circular, entire and } \\
\text { convex }\end{array}$ & Tiny Rod & - & + & + & - & - & - & Shigella dysenteriae \\
\hline $\begin{array}{c}2 \mathrm{~mm} \text {, pale coloured, } \\
\text { circular, entire and } \\
\text { convex }\end{array}$ & Rod & - & + & - & + & - & + & $\begin{array}{l}\text { Salmonella } \\
\text { enteritidis }\end{array}$ \\
\hline
\end{tabular}

Table 1: Colonial Morphology and Biochemical Characteristics of the Isolates

Cat-Catalase; Ind-Indole; Cit-Citrate; Oxid-Oxidase; Coag-Coagulase 


\begin{tabular}{|c|c|c|c|}
\hline S/ N & Bacteria & No. of Occurrence & Percentage (\%) ) \\
\hline 1 & Escherichia coli & 72 & 21.43 \\
\hline 2 & Pseudomonas aeruginosa & 51 & 15.18 \\
\hline 3 & Staphylococcus aureus & 45 & 13.40 \\
\hline 4 & Streptococcus pyogenes & 33 & 9.82 \\
\hline 5 & Klebsiella pneumonia & 32 & 9.52 \\
\hline 6 & Bacillus cereus & 29 & 8.62 \\
\hline 7 & Micrococcus luteus & 31 & 9.23 \\
\hline 8 & Shigella dysenteriae & 24 & 7.14 \\
\hline 9 & Salmonella enteritidis & 19 & 5.65 \\
\hline & Total & 336 & 100.00 \\
\hline
\end{tabular}

Table 2: Number and Percentage of Occurrence of Each Bacterium Isolated in the 80 Samples

\begin{tabular}{|c|c|c|c|}
\hline Abattoir & Coliform Count (Cfu/ MI) & Aerobic Count (Cfu/ MI) & Total Microbial Count (Cfu/ MI) \\
\hline Choba & $1.06 \times 10^{7}$ & $1.02 \times 10^{7}$ & $2.08 \times 10^{7}$ \\
\hline Rumuokoro & $1.10 \times 10^{7}$ & $1.11 \times 10^{7}$ & $2.21 \times 10^{7}$ \\
\hline Ogbunnabali & $1.21 \times 10^{7}$ & $1.18 \times 10^{7}$ & $2.39 \times 10^{7}$ \\
\hline Trans Amadi & $1.55 \times 10^{7}$ & $1.12 \times 10^{7}$ & $2.67 \times 10^{7}$ \\
\hline Total & $4.92 \times 10^{7}$ & $4.43 \times 10^{7}$ & $9.35 \times 10^{7}$ \\
\hline Mean $(\overline{\boldsymbol{x}})$ & $1.23 \times 10^{7}$ & $1.1075 \times 10^{7}$ & $2.3375 \times 10^{7}$ \\
\hline
\end{tabular}

Table 3: Mean Values of Microbial Load for the Different Abattoirs

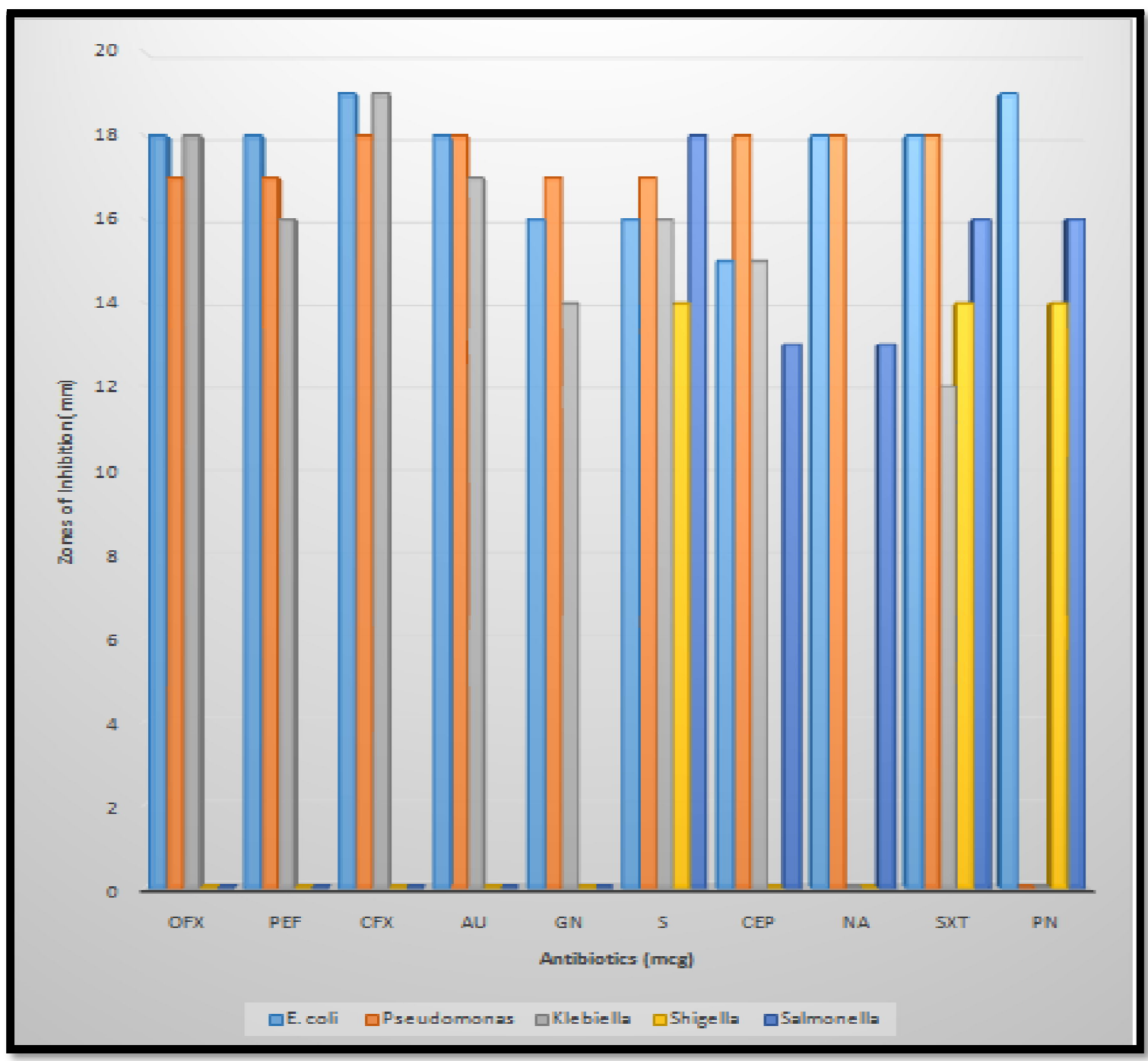

Figure 1: Shows Zones of Inhibition Produced Against Gram-Negative Bacteria Isolates 


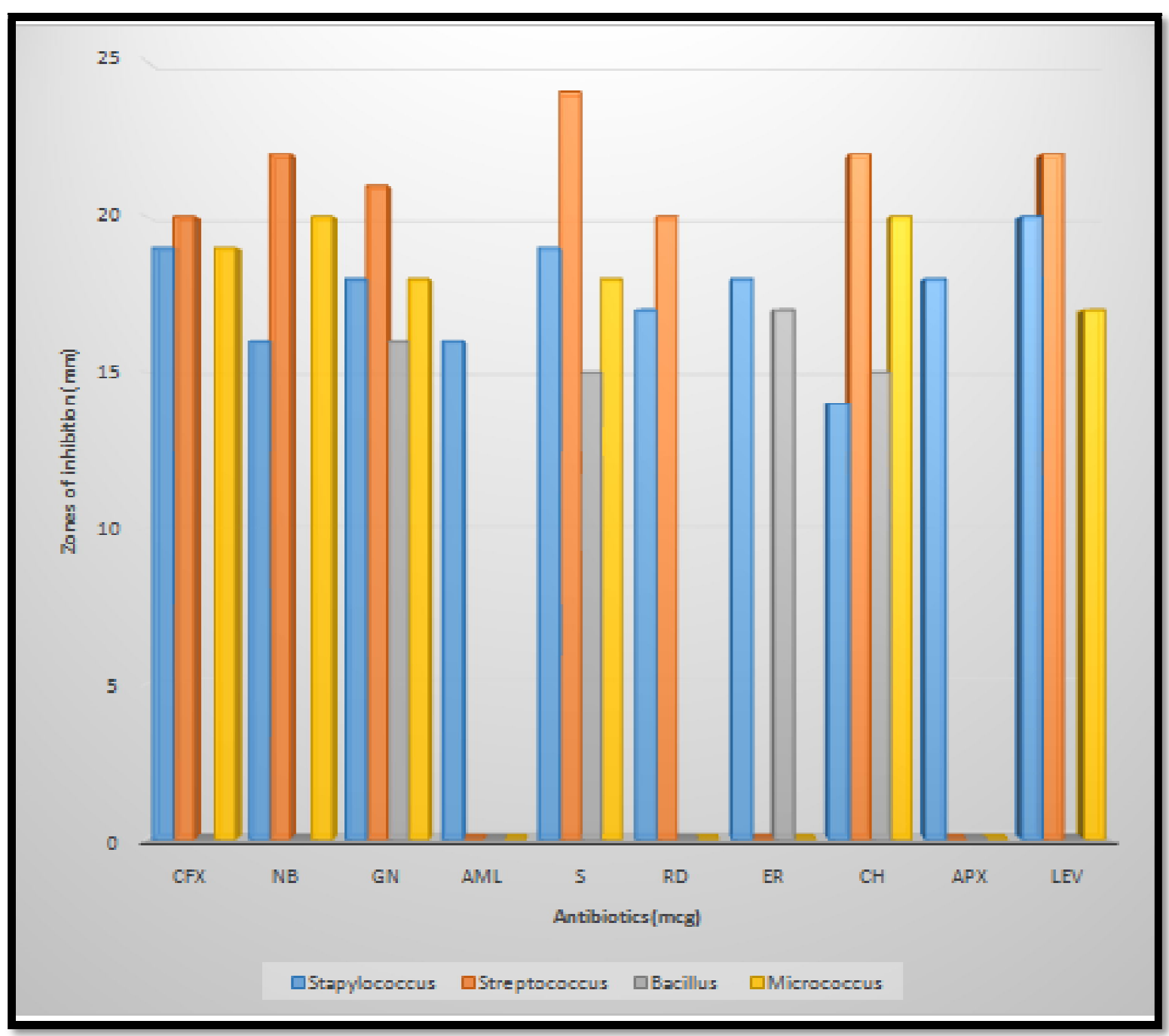

Figure 2: Shows Zones of Inhibition Produced against Gram-Positive Bacteria Isolates

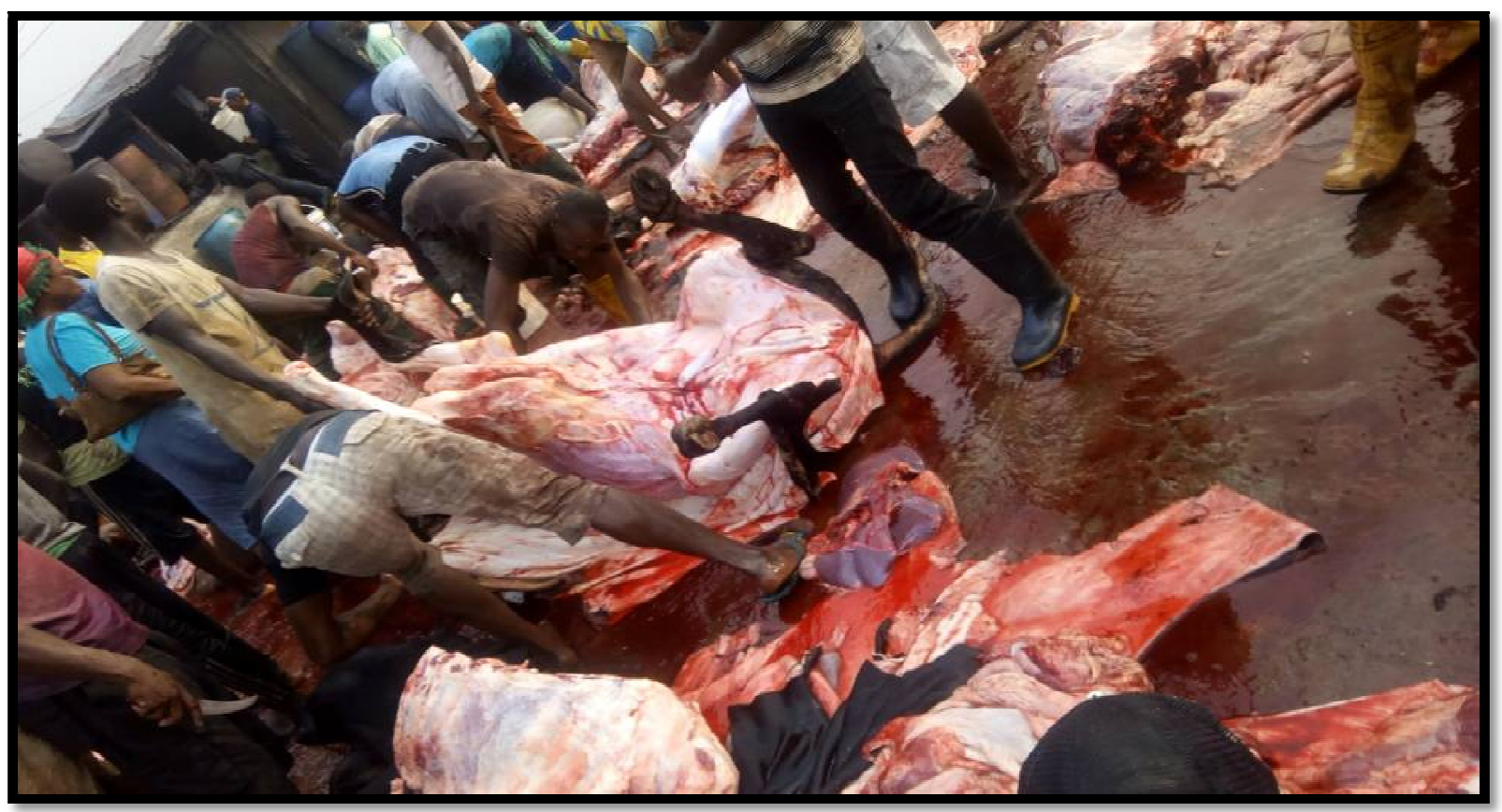

Figure 3: A Typical Scene at One of the Abattoirs Showing the Crude and Unhygienic Slaughter of a Cow on the Bare Floor with Many People Moving around 


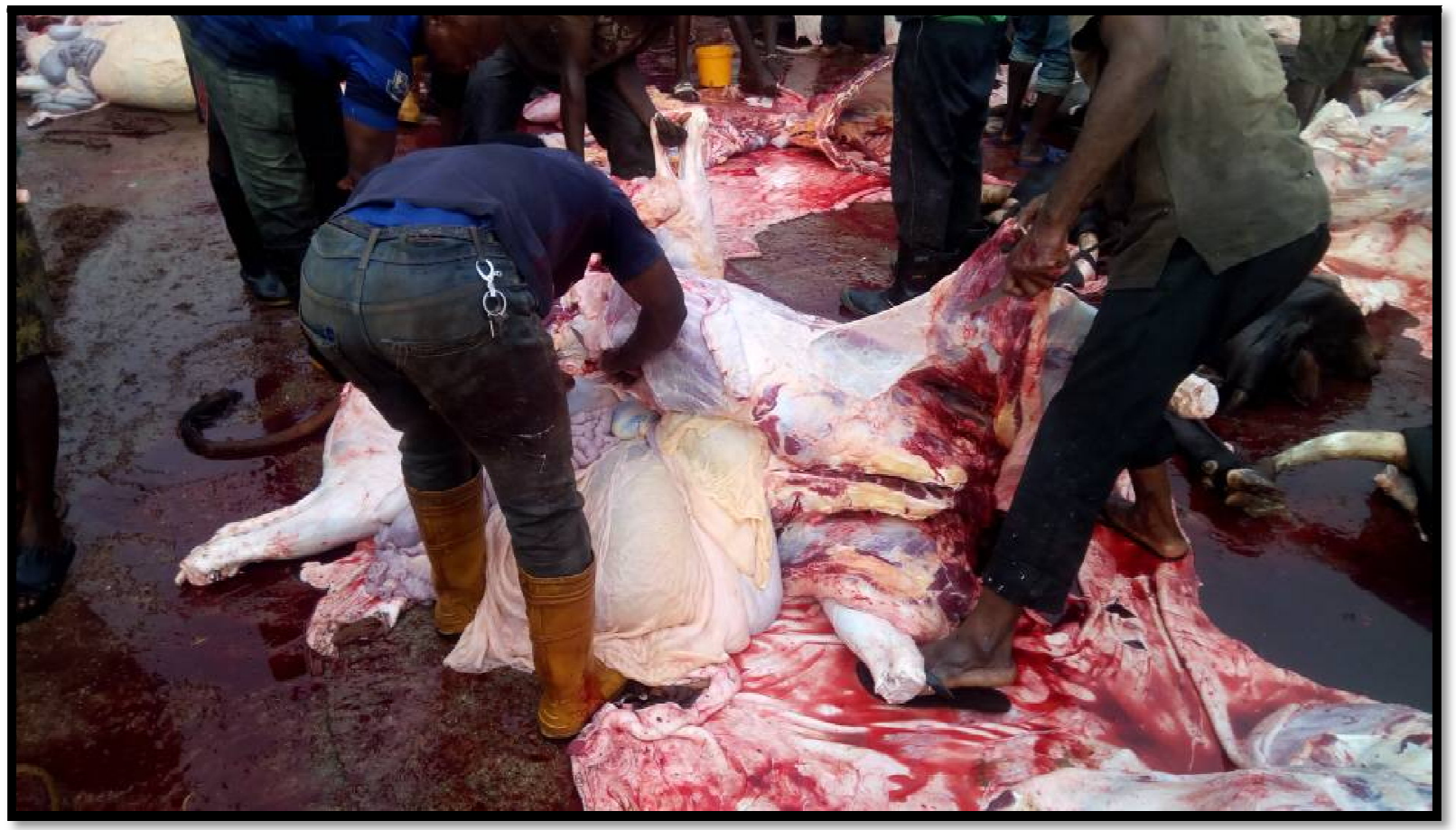

Figure 4: Another Scene at the Abattoir Showing the Crude and Unhygienic Method of Slaughtering Cow on the Bare Floor with No Running Water

\section{Discussion}

The bacteria isolated and identified were the following genera; Escherichia, Pseudomonas, Staphylococcus, Streptococcus, Klebsilella, Bacillus, Micrococcus, Shigella and Salmonella. E. coli had the highest incidence as it accounted for $21.43 \%$ of the bacterial isolates as shown in Table 2. This is in line with the works earlier done by Eze and Ikeri (2010), and Adesemonye et al. (2006). E. coli being the highest occurring of the nine bacteria isolated is also in conformity with earlier reports that E. coli is a major meat contaminant (Fasanmi \& Sansi, 2008). This was followed by pseudomonas and Staphylococcus species which accounted for $15.18 \%$ and $13.40 \%$ respectively. It is worthy of note that regardless of the incidence of these pathogens, they all have the potential to cause extensive damage to the consumer.

The least encountered bacterium was salmonella which accounted for $5.65 \%$ of the total bacterial count. The presence of these microbes on the tables used for displaying meat is an indication that meat placed on such tables could have been contaminated in the process. Nevertheless, other factors such as unhygienic practices may also account for the contaminations of the tables after the daily normal sales. These findings were similar to the reports of Edema et al. (2005) on the microbial safety and quality of ready-to-eat foods in Nigeria. Biological contaminants such as bacteria, viruses, fungi, protozoa and helm in this constitute the major cause of food-borne diseases with varying degree of severity, ranging from mild disposition to chronic or life-threatening illness, or both. In developing countries, such contaminants are responsible for food borne diseases such as cholera, campylobacteriosis, E.coli gastroenteritis, Salmonellosis, Shigellosis among others (Edema et al., 2005).

The mean value of the coliform count from the entire sample was $1.27 \times 10^{7} \mathrm{cfu} / \mathrm{ml}$, while the mean value of the aerobic colony count was $1.21 \times 10^{7} \mathrm{cfu} / \mathrm{ml}$ with a significant difference $(\mathrm{P}<0.05)$.

The mean microbial counts for all the eighty samples was 2.34 × $10^{7} \mathrm{cfu} / \mathrm{ml}$ with the highest and lowest counts observed in Trans-amadi and Choba abattoirs respectively (see Table 3). These mean total microbial counts ranged between $2.08 \times 10^{2} \mathrm{cfu} / \mathrm{ml}$ and $2.67 \mathrm{x} 10^{2} \mathrm{cfu} / \mathrm{ml}$. These values exceed the Food and Agricultural Organization (FAO) and World Health Organization (WHO) standard limit of $1.0 \times 10^{2} \mathrm{cfu} / \mathrm{ml}$ for food products and water (Fasanmi, Olukole \& Kehinde, 2009). These, thus, pose a serious public health problem to the consumers of such meats and it is also an indication of the level of hygiene practices at the various abattoirs in Port Harcourt. This shows that a wide variety of foods including meat have been associated with the diarrhoeal type of food poisoning resulting from bacillus spp.

The presence of bacterial species such as E.coli and shigella in the samples could be an indication of faecal contamination of meat through water used in washing the meat and/ or hands or unhygienic handling of meat right from the slaughter slabs to the tables (Edema et al., 2001). The high incidence of isolated pathogens at these abattoirs is not surprising considering the large number of people engaged in abattoir procedures as seen in Fig 3 and 4 above.

Also, the unhygienic condition of the tables on which the meats are displayed for sale might also contribute to the contamination. The knives and cutlasses used in cutting meat are also important contaminants since they are rarely sterilized due to lack of facilities for sterilization of tools at the abattoirs. Furthermore, the indiscriminate use of these tools in cutting of 
offal, like the intestines, constitute another possible source of meat contamination as the gut contents can easily be spread to the table and the entire meat to be sold (Fasanmi et al., 2009).

The antibiotics susceptibility test revealed that although E. coli was susceptible to all the antibiotics used the salmonella and shigella species were multiply resistant to the fluoroquinolones, gentamic in, cephalex in, amoxicillinclavulanic acid and ampicillin (see Figure 2).

The antibiotic susceptibility test among the Gram-positive bacteria revealed that Staphylococcus aureus was susceptible to all the antibiotics used. This was followed by Streptococcus spp which showed resistance to amoxillin, erythromycin and also ampicillin/ cloxacillin. Bacillus spp showed the highest level of resistance against the antibiotics. The intermediate zones of inhibition among the gram-positive bacteria ranged between $14 \pm 0.03$ as seen in staphylococcus against chloramphenicol and $24 \pm 0.3$ as seen in streptococcus against streptomycin.

The susceptibility results of bacteria isolated showed that they are resistant to most of the antibiotics tested. Gramnegative organisms are more resistant than the gram-positive; this is expected because of intrinsic nature of gram-negative cell wall. The gram-negative bacteria isolated include E. coli, pseudomonas, Klebsiella, Shigella and Salmonella species which harbour series of antibiotic resistant genes which can be transferred horizontally to other bacteria species.

The resistance shown by bacillus species to most of the antibiotics could be attributable to their usage in animal husbandry. Indiscriminate use or use of sub-therapeutic doses in treating bacterial infections in animals could have the adverse consequences of promoting the selection and prevalence of drug resistant species and possible transfer of antibiotic resistance among species with a range of human health consequences.

\section{Conclusion}

The variety of pathogens isolated in this study showed that the surface of tables used for the display of meat at the abattoirs sampled were highly contaminated and this could be as a result of unhygienic practices displayed by workers there. Lack of clean water source for washing and cleaning, unhygienic handling of products, non-disinfection of tables before and after use for display of meat and non-sterilization of working tools is the norm at the different sites. Furthermore, there is almost a complete absence of regulatory authorities who are supposed to carry out periodic inspections aimed at ensuring the maintenance of acceptable standards of hygiene and other best practices. While the use of antibiotics has been proven to be effective means for the prevention and control of bacterial infection, the increase in antibiotic resistance strains of a number of pathogenic bacteria has caused great concern, and this is as a result of rising indiscriminate use of antibiotics in treating animals or in their feeds. This study recommends that proper hygiene must be maintained by workers in the slaughter houses, there is also need for stringent and consistent inspection of slaughter houses by the relevant authorities. Consumers of meat from slaughter houses, should as a matter of importance, cook them to a minimum temperature of $80^{\circ} \mathrm{C}$ for at least 20 to 30 minutes; the temperature and time at which most of the microorganisms are killed. Finally, the application of stringent hygiene practices along the food chain and prudent use of antibiotics in animal husbandry which are essential for the control of further emergence of antibiotic resistance should be observed.

\section{References}

i. Abiade-Paul, C. U., Kene, I.C. \& Chah, K. F (2006). Occurrence and Antibiogram of Salmonellae in effluent from Nsukka Municipal abattoir. Nigeria Vet. Journal, (1), 48-53.

ii. Alonge, D. O. (2005). Textbookof meat hygiene in the tropics. Farmoe Press, Ibadan.

iii. Cheesbrough, M. (2005). District laboratory practice in Tropical countries. Cambridge University Press. United Kingdom.

iv. Clarence, S. Y., Obinna, C. N., \& Shalon, N. C. (2009). Assessment of bacteriological quality of ready-to-eat food (meat pie) in Benin city metropolis, Nigeria. African Journal of Microbiol. Res., 3 (6), 390-395.

v. Edema, M. O., Omem, A.M. \& Fapetu, O. M. (2001). Microbiology and physicochemical analysis of different sources of drinking water in Abeokuta, Nigeria. Nigerian Journal of Microbiolol., 15 (1), 57-61.

vi. Elmossalami, K. (2003). Attachment of Listeria Microcytogene to stainless steel sources of various temperature and PH values. Journal of Food Science, (53), 103-111.

vii. Fasanmi, O. G., Olukole, S.G \& Kehinde, O. O. (2009). Microbial studies of table scrapings from meat stalls in Ibadan metropolis, Nigeria: Implications on meat hygiene. African J. Biotech, 9 (21), 3158-3162.

viii. Fasanmi, O. G., \& Sanusi, A. A. (2005). Essentials of meat and milk inspection and hygiene. 1st Ed., Published by Tunmid Printronic, Ibadan.

ix. Garcia, I. (2007). Microscopic examination of natural sepsis bacterial populations from alpine streams. Canadian Journal of Microbiology, 3 (3), 170-184.

x. Gill, C. O. \& Jones, T. (2005). Microbiological sampling of carcasses by excision or snubbing. Journal of Food Protection, 65 (2), 107-111.

xi. Harrigan, W. F. \& McCance, M. E (1976). Laboratory methods in food and diary Microbiology. Academic Press London. United Kingdom.

xii. Iroha, I.R., Ugbo, E.C., Lang, D. C., Orhji, A. E. \& Ayogu, T. E. (2011). Bacteria contamination of raw meat sold in Abakaliki, Ebonyi State, Nigeria. Journal of Public Health and Epidemiology, 3 (2), 49-53. 
xiii. Mohammed, O., Shimelis, D., Admasu, P. \& Feyera, T. (2014). Prevalence and Antimicrobial Susceptibility Pattern of E. Coli Isolates from Raw Meat Samples Obtained from Abattoirs in Dire Dawa City, Eastern Ethiopia. International Journal of Microbiological Research, 5 (1), 35-39.

xiv. Marriott, J. A. (2004). Microbial Problems in Handling and Storage of fresh meats. Journal of Applied Bacteriology, (7), 433-441.

xv. Mboto, C. I., Agbo, B. E., Ikpoh, I. S., Agbor, R.B., Udoh, D. I., Ambo, E. E., \& Ekim, M. A. (2012). Bacteriological study of raw meat of Calabar Abattoir with public health and veterinary importance. Journal of Microbiol. Technology Res., 2 (4), 529-532.

xvi. Nwachukwu, V. C. (2006). Analysis of Nsukka municipal abattoir solid waste and its microbial contents in Enugu State. Nigeria and Preventive Medicine, University of Nigeria, Nigeria.

xvii. Nwanta, J. A., Onumkwo, J. I., Ezenduka, V. E., Phil-Eze, P.O. \& Egege, S. C. (2008). Abattoir operation and waste management in Nigeria: A review of challenges and prospects. Sokoto Journal of Vet. Sciences, 7 (2), 61-67.

xviii. Ogbonnaya, C. (2008). Analysis of Groundwater pollution from Abattoir waste in Minna Nigeria. Res. Journal of Sciences, 2 (4), 74-77.

xix. Okonko, I.O., Adejoye, O. D., Ogunnusi T. A., Fajobi E. A. \& Shittu, O. B. (2008). Microbiology and physio-chemical analysis of different water samples used for domestic purpose in Abeokuta and Ojota, Lagos State, Nigeria. African Journal of Biotechnology, 7 (3), 617-621.

xx. Okonko, I. O, Ukut, I.D.E, Ikoh, I. S., Nkang, A. O, Udeze, A. O., Babalola, T. A., Mejeha, O. K. \& Fajobi, E.A. (2010). Assessment of bacteriological quality of fresh meats sold in calabar metropolis, Nigeria. Electronic Journal of Env. Agric. And Food Chemistry, 9 (1), 89-100.

xxi. Omoruji, I. M, Wogu, M.D. \& Eraga E.M (2011). Bacteriological quality of beef-contact surfaces, air microflora and waste waters from major abattoirs located in Benin City, Southern Nigeria. International Journal of Biosciences, 1 (3), 57-62.

xxii. Onuoha, S. C., Eluu, S. C. \& Okata, M.O. (2016). In-vitro Antimicrobial Resistance of Shigella and Salmonella species Recovered from Abattoir effluent in Afikpo, South Eastern Nigeria. International Journal of Current Microbiology and Applied Sciences, 5 (4), 488-497.

xxiii. Ugwu, M. C., Abuchi, U., Gugu, T., Ugwu, B. C., Okezie, U., Unachukwu, C. \& Stanley, C. N. (2016). Incidence and antibiotic susceptibility pattern of Gram Negative bacteria isolated from aprons of meat vendors in Awka, Anambra State, Nigeria. World Journal of pharmacy and pharmaceutical Sciences, 5 (4), 269-277.

xxiv. World Health Organisation [WHO] (2003). Manual for the laboratory identification and antimicrobial susceptibility testing of bacterial pathogens of public health concern in the developing world. World Health Organization, Geneva.

xxv. Yen, K. M. (2003). Biofilms in food processing. Food control, 1-18

xxvi. Yousuf, A. H. M., Ahmed, M. K, Yeasmin, S. Ahsam, N \& Rahman M. M. (2008). Prevalence of Microbial load in Shrimp, Prenaeus monodon and prawn, Macrobachium rosenbergii from Bangladesh. World Journal of Agric. Science, 4 (5), 852-885.

xxvii. Zweifer, C., Fischer R. \& Stephen R. (2008). Microbiological contamination of pig and cattle carcasses in different small scale Swiss Abattoir. Meat Sciences, (78), 225-231. 